\title{
Aplikasi IoT untuk Kendali Beban Listrik
}

\author{
Asnil $^{1}$, Krismadinata ${ }^{2}$, Fivia Eliza ${ }^{3}$, Irma Husnaini ${ }^{4}$ dan Ricky Maulana ${ }^{5}$ \\ ${ }^{12345}$ universitas Negeri Padang \\ Jl. Prof. Dr. Hamka, Air Tawar-Padang, Indonesia \\ asnil81@ft.unp.ac.id, krisma@ft.unp.ac.id, fiviaeliza@ft.unp.ac.id, irma hnni@ft.unp.ac.id, ricky.maulana@ft.unp.ac.id
}

\begin{abstract}
Internet of thing (IoT) is a system that will change the order of human life and industrial operations. In the future, objects that are operated daily with human interaction will be equipped with internet connectivity which is equipped with various sensors so that they are able to communicate and act on the information obtained without human intervention. The problem is that the ecosystem has not been fully developed as well as from the world of education which will prepare its human resources. Apart from that, the industrial sector which is predicted to be the largest user is still considering various things such as cost, security, non-conformity with the existing system and the ability of its resources. The system created is an effort to develop knowledge in the IoT field as an effort to bridge the need for human resources, especially at the Vocational High School (SMK) level. This IoT application for electrical load control is designed and built using the main components of NodeMcu V3, 4 channel relay, and Android with the Blynk application installed. Electrical load control commands are given using the Blynk application via Android and delivered to the NodeMcu V3 module using a Wifi intermediary and from NodeMcu V3 forwarded to 4 channel relays to control electrical loads in the form of ON and OFF. The results of the test show that the system built can operate properly in controlling electrical loads
\end{abstract}

Keywords - IoT, NodeMcu V3, ESP8266, Electrical load.

\begin{abstract}
Abstrak - Internet of thing (IoT) adalah suatu sistem yang akan mengubah tatanan kehidupan manusia serta operasional industri. Benda yang sehari-hari dioperasikan dengan interaksi dari manuasia, kedepanya akan dilengkapi dengan konektivitas internet yang dilengkapi dengan berbagai macam sensor sehingga mampu berkomunikasi dan bertindak berdasarkan informasi yang didapatkan tanpa adanya campur tangan manusia. Permasalahnya adalah ekosistem yang belum terbangun secara menyeluruh serta dari dunia pendidikan yang akan menyiapkan sumber daya manusianya. Selain dari itu, sektor industri yang diperkirakan akan menjadi pengguna terbesar masih mempertimbangkan berbagai hal seperti biaya, keamanan, ketidaksesuaian dengan sistem yang sudah ada serta kemampuan sumber daya yang dimiliki. Sistem yang dibuat ini merupakan upaya untuk mengembangkan pengetahuan dibidang IoT sebagai salah satu upaya dalam menjembatani kebutuhan terhadap sumber daya manusia khususnya pada level SMK. Aplikasi IoT untuk kendali beban listrik ini dirancang dan dibangun menggunakan komponen utama NodeMcu V3, relay 4 channel, dan Android yang sudah terinstal aplikasi Blynk. Perintah kendali beban listrik diberikan menggunakan aplikasi Blynk melalui Android dan disampaikan ke modul NodeMcu V3 menggunakan perantara wifi serta dari NodeMcu V3 diteruskan ke relay 4 channel untuk mengendalikan beban listrik berupa ON dan OFF. Hasil dari pengujian menunjukan system yang dibangun dapat beroperasi dengan baik dalam mengendalikan beban listrik.
\end{abstract}

Kata kunci- IoT, NodeMcu V3, ESP8266, Beban listrik.

\section{Pendahuluan}

Tidak bisa dipungkiri bahwa perkembangan teknologi saat ini sangat pesat dan salah satu yang sedang berkembang adalah pemanfaatan internet dalam segala hal atau yang popular dengan sebutan Internet of Thing (IoT). Internet of Thing (IoT) adalah sebuah ekosistem perangkat komputasi yang saling terkait yang dilengkapi dengan sensor atau identifikasi unik lainya sehingga mampu berkomunikasi dan bertindak berdasarkan informasi yang didapatkan tanpa adanya campur tangan manusia [1]. IoT merupakan suatu evoluisi lanjutan dari internet dan memiliki dampak yang sangat luas sehingga dapat mengubah tatanan kehidupan manusia ataupun sektor perindustrian yang diperkirakan akan menjadi pengguna terbesar dari system IoT. Juga bisa dikatakan sebuah konsep yang bertujuan untuk memperluas manfaat dari internet yang tersambung secara terus menerus sehingga peralatan apa saja termasuk benda hidup yang semuanya tersambung ke jaringan local atau global melalui sensor yang tertanam dan selalu aktif [2]. Gambar 1 merupakan ilustrasi jika system IoT sudah terbangun dengan baik dan semua aktivitas manusia akan terhubung ke internet [2].

Permasalahanya sekarang adalah system IoT itu sendiri belum terbangun dengan baik terutama dari segi sumber daya manusianya. Tantangan terbesar yang memungkinkan akan menjadi hambatan adalah menjembatani kesenjangan antara dunia fisik dan dunia informasi, bagaimana menyusun jaringan komunikasinya karena sangat kompleks, system keamanan, biaya untuk investasi awal yang cukup mahal serta kesesuaian dengan 
system yang sudah ada [3]. Selain dari itu, implementasi teknologi IoT membutuhkan analisa yang mendalam mengenai pembangunan arsitektur protokol umum yang memungkinkan akan menjadi standar baru karena akan lebih banyak penyesuaian dengan lingkungan, demografi, geografis dan teknologi jaringan yang dapat mendukung kesejahteraan rakyat [4]. Salah satu himbauan dari pemerintah dalam menyikapi perkembangan teknologi di bidang IoT adalah peran generasi muda khususnya yang berada pada jenjang Sekola Menengah Kejuruan (SMK) untuk dipersiapkan lebih dini [5]. Hal ini berkaitan dengan kesiapan mereka untuk bersaing dalam mengimplementasikan dan menghasilkan produk IoT yang dapat bersaing dengan produk IoT Masyarakat Ekonomi Asean (MEA).

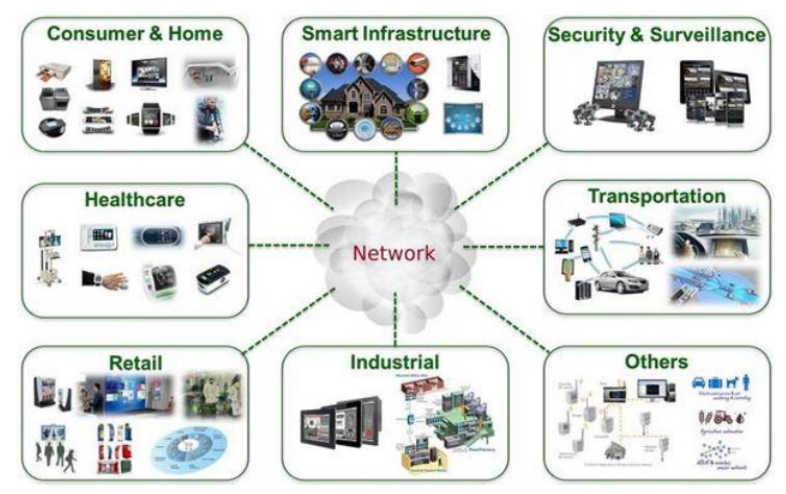

\section{Gambar 1. Semua aktivitas manusia terhubung ke internet}

Tulisan ini membahas mengenai penerapan konsep IoT untuk kendali beban listrik terutama untuk beban listrik rumah tangga seperti lampu atau beban listrik lainya. Perangkat utama yang digunakan adalah ESP 8266, Android menggunakan aplikasi Blynk dan relay. Sistem yang dibuat diharapkan dapat digunakan sebagai dasar untuk mempelajari aplikasi IoT dalam menambah wawasan mengenai perkembangan teknologi yang menggunakan IoT.

\section{NodeMcu V3}

NodeMcu V3 yang digunakan merupakan firmware dari ESP8266 dengan development kitnya serta bersifat opensorce sehingga mudah untuk mengembangkan produk yang berbasis IoT [6]. Memiliki beberapa pin GPIO pada sehingga memungkinkan untuk menghubungkan dengan perangkat lain dan mampu menghasilkan PWM, I2C, SPI, dan komunikasi UART [7]. Secara umum, NodeMcu ini merupakan turunan dari modul platform IoT yang masih merupakan kelompok ESP8266 tipe ESP-12. Fungsinya juga bisa dikatakan menyerupai dengan platform arduino uno, namun yang membedakan khusus pada hubungan ke internetnya [8].

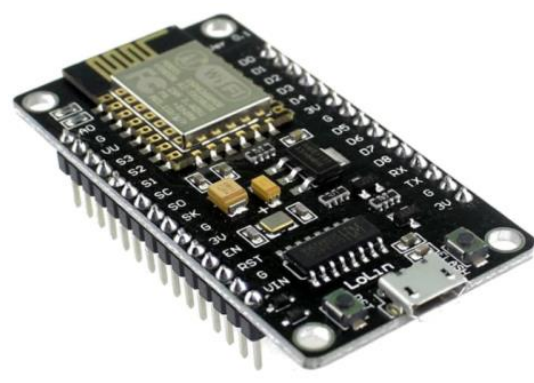

Gambar 2. Bentuk fisik NodeMcu V3

Ada perbedaan mendasar di NodeMcu V3, yaitu pada pin Vin dan USB. Dimana Vin bisa 7 volt sampai 12 volt dan pada USB dipertahankan pada tegangan 5 volt. Selain bersifat open source, keunggulan lain dari NodeMcu V3 ini adalah harga yang terjangkau dari segi ekonomi. Gambar 3 adalah bentuk Pinout dari NodeMcu V3.

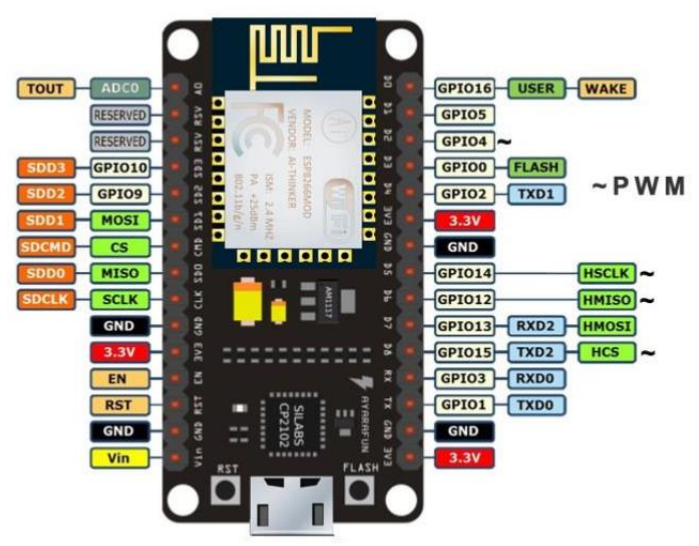

Gambar 3. PinOut NodeMcu V3

Relay

Relay yang digunakan pada aplikasi IoT yang dibuat adalah modul relay 4 channel seperti pada gambar 4 . Modul relay ini memiliki kemampuan beban maksimum AC 250 volt 10 A dan beban DC 30 Volt 10 A dengan tegangan kerja 5 Volt (active low).

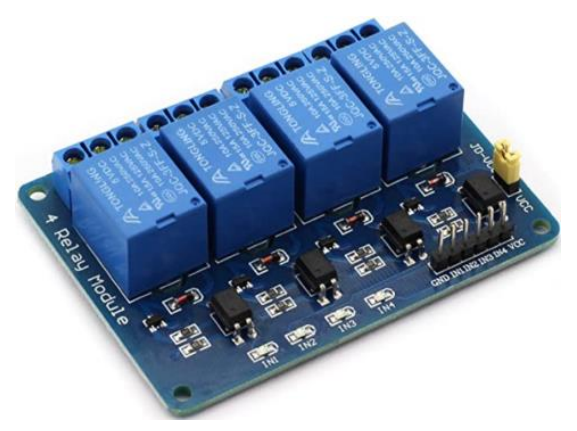

Gambar 4. Modul relay 4 channel 
Komponen utama relay secara umum adalah contact dan coil, dimana contact merupakan sejenis saklar yang kerjanya dipengaruhi oleh arus listrik dari coil. Sedangkan coil merupakan sebuah gulungan kawat. Kerja relay berdasarkan prinsip elektromagnetik, arus yang mengalir melalui kumparan akan membuat inti besi menjadi magnet dan akan menarik jangkar yang mengakibatkan contact terhubung sehingga arus dapat mengalir.

\section{Blynk}

Blynk merupakan wadah yang bisa digunakan untuk membuat antarmuka grafis dalam pengembangan aplikasi IoT. Aplikasi ini dapat digunakan untuk kendali modul Arduino, Raspberry Pi, ESP8266 melalui internet berbasis aplikasi OS Mobile (iOS dan Android). Aplikasi Blynk dapat di download dan install melalui PlayStore secra gratis. Aplikasi Blynk dapat digunakan untuk mengontrol apapun dari jarak jauh dengan catatan harus terhubung ke internet dengan koneksi yang stabil. Gambar 5 merupakan bentuk tampilan aplikais blynk di Android yang akan digunakan pada system yang dibuat.

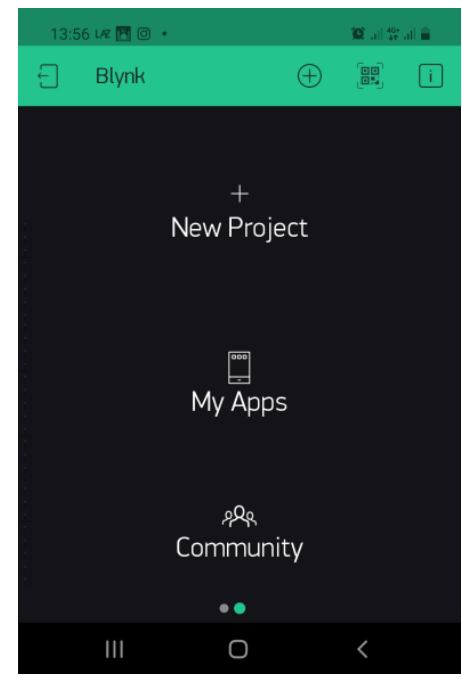

\section{Gambar 5. Tampilan aplikasi Blynk setelah di instal pada Android}

\section{Metode}

Metode yang digunakan dalam menyelesaikan system yang dibuat adalah dengan cara rancang bangun. System yang dibuat dirancang untuk mengendalikan beban listrik terutama untuk beban listrik rumah tangga. Untuk pengujian, beban listrik yang digunakan adalah lampu sebanyak 4 buah. Pada gambar 6 dapat dilihat bentuk blok diagram dari system yang akan dibuat.

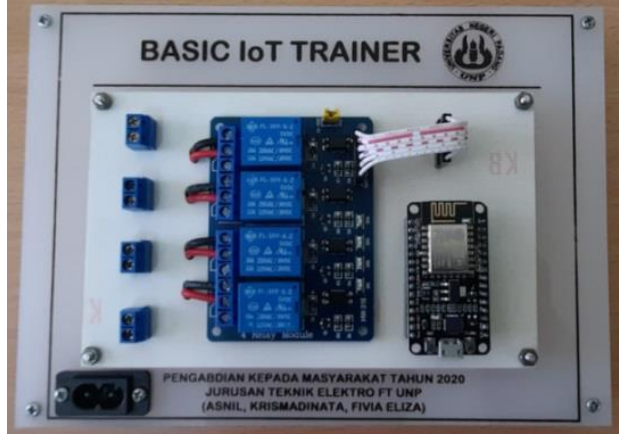

Gambar 6. Blog diagram sistem

Lampu adalah sebagai beban untuk pengujian kendali beban listrik rumah tangga menggunakan IoT. Perintah untuk kendali beban listrik menggunakan aplikasi Blynk yang diinstal pada Android. Kemdian perintah tersebut dikirim ke relai untuk mematikan atau menghidupkan lampu. Perintah dikirim dari aplikasi Blynk ke NodeMcu V3 sebagai perangkat utama IoT melalui wifi yang kemudian diteruskan ke relay. Perintah pemograman pada NodeMcu V3 ditulis menggunakan aplikasi Arduino IDE yang pada system ini menggunakan Arduino Ide 1.8.13.

\section{HASIL DAN PEMBAHASAN}

Implementasi dari dari aplikasi IoT untuk kendali beban listrik dapat dilihat pada gambar 7 yang dikemas dalam bentuk purwarupa Basic IoT Trainer .

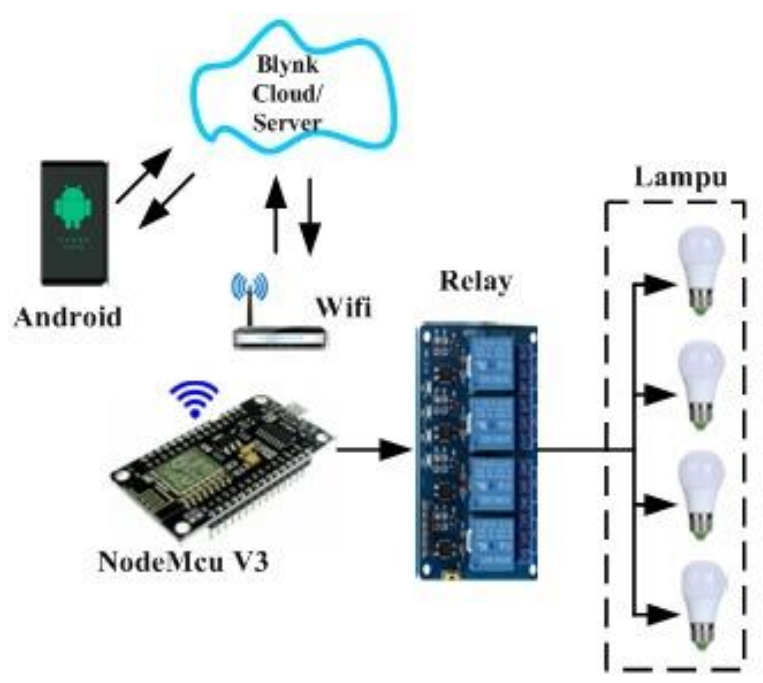

\section{Gambar 7. Purwarupa aplikasi IoT untuk kendali beban listrik.}

Komponen utama purwarupa pada gambar 7 terdiri dari NodeMcu V3, relay 4 channel, terminal beban. Pemograman pada NodeMcu V3 dibuat menggunakan aplikasi Arduino Ide 1.8.13. Pada gambar 8, dapat dilihat kode program yang digunakan untuk NodeMcu V3 dalam mengendalikan beban listrik. 


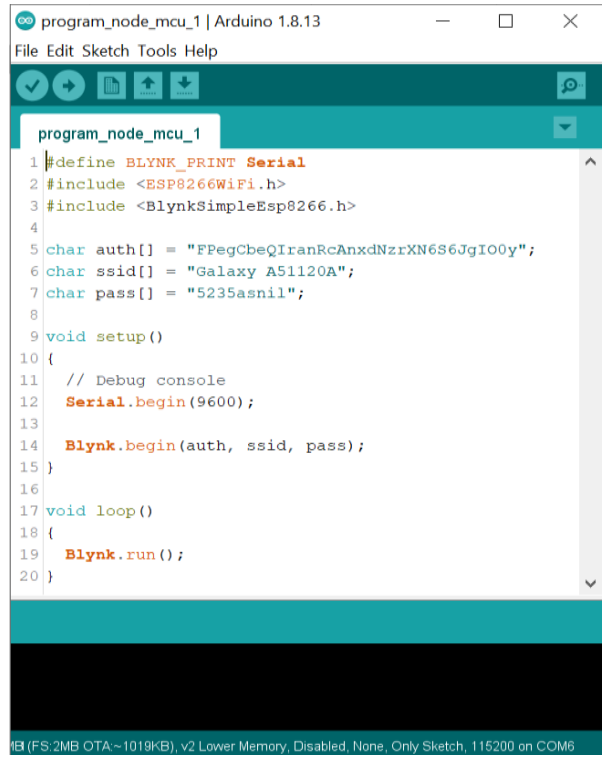

Gambar 8. Kode program NodeMcu V3 menggunakan Arduino IDE

Sedangkan bentuk aplikasi Blynk yang dibuat di Android untuk kendali beban listrik dapat dilihat pada gambar 9.

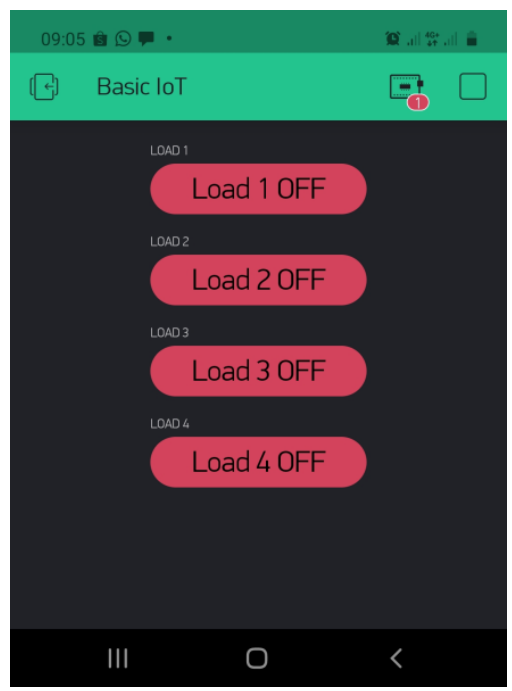

Gambar 9. Tampilan aplikasi blynk untuk kendali beban listrik

Pada gambar 9 terdapat empat buah tombol berwarna merah dengan latar tulisan Load 1 OFF, Load 2 OFF, Load 3 OFF dan Load 4 OFF. Keempat buah tombol ini berwarna merah pada saat kondisi beban dalam keadaan Off atau mati. Sedangkan jika kondisi beban dalam keadaan terhubung atau beban lampu hidup maka warna tombol di stel berubah menjadi warna hijau. Kemudian semua tulisan berubah menjadi Load 1 ON, Load 2 ON, Load 3 ON dan Load 4 ON seperti pada gambar 10.

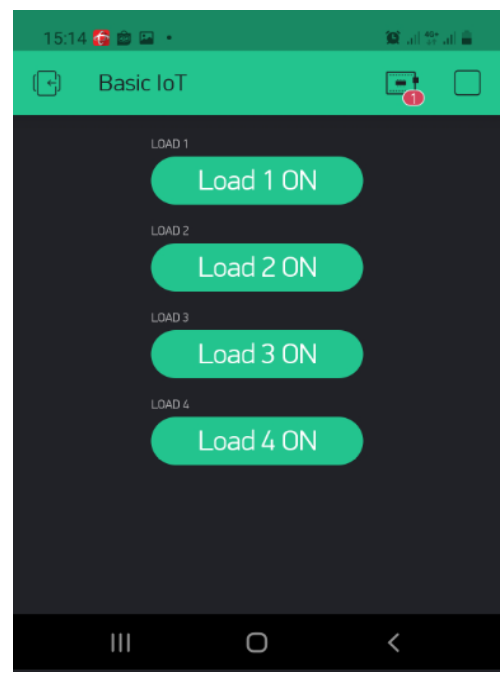

Gambar 10. Tampilan aplikasi blynk pada saat kondisi beban terhubung

Angka 1 berwarna warna merah pada sudut kana atas gambar 10 menandakan bahwasanya aplikasi sudah terhubung dengan sistem.

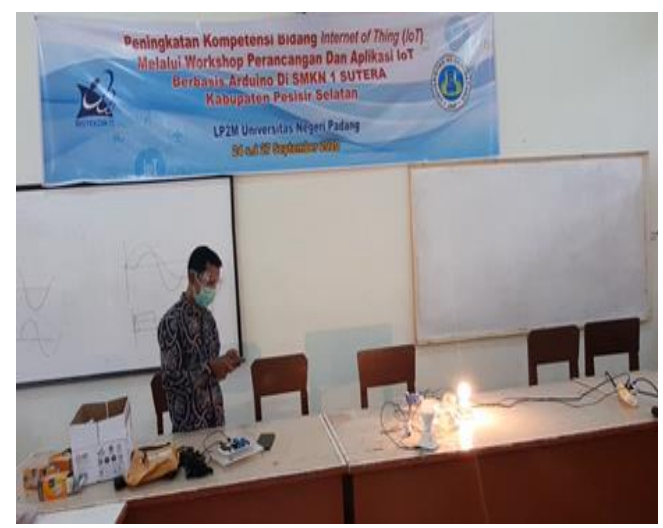

(a)

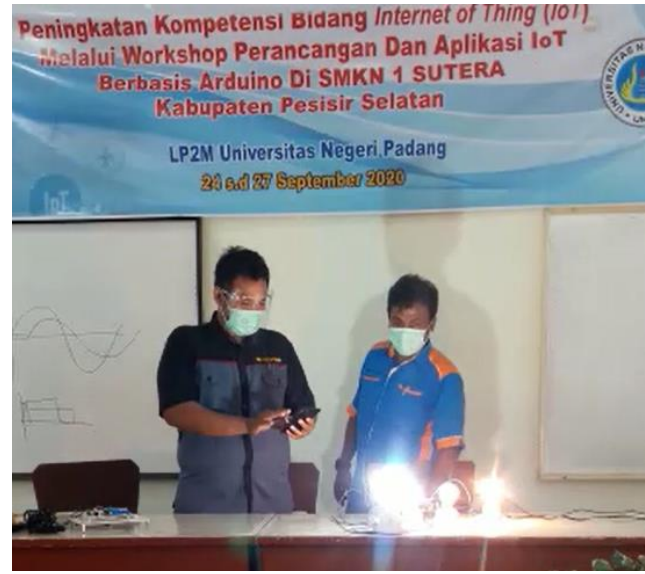

(b)

Gambar 11. (a) dan (b) Uji sistem aplikasi IoT untuk kendali beban listrik 
Dalam upaya penyebarluasan ilmu pengetahuan, maka sistem yang dibuat juga digunakan pada kegiatan pelatihan yang di laksanakan di SMK N 1 Sutera pada tanggal 24 s.d 27 September 2020. Gambar 11 (a) dan gambar 11(b) merupakan kegiatan uji dari system aplikasi IoT untuk kendali beban listrik. Pada pengujian menggunakan beban listrik berupa lampu sebanyak 4 buah dengan daya yang berbeda-beda. Sedangkan untuk koneksi wifi menggunakan wifi yang ada pada Android masing-masing peserta pada kegiatan tersebut.

\section{PENutuP}

Dari pengujian yang dilakukan maka dapat diambil kesimpulan bahwa system aplikasi IoT untuk kendali beban listrik yang dibuat bisa beroperasi sesuai dengn yang direncanakan. Dalam pengujian menggunakan 4 buah bola lampu yang dikendalikan menggunakan android menggunakan perantara wifi. Untuk pengembangan dan penyebarluasan ilmu pengetahuan, aplikasi ini juga digunakan pada kegiatan pengabdian kepada masyarakat dan system yang dibuat dapat beroperasi dengan baik.

\section{REFERENSI}

[1] D. Vuksanović, J. Ugarak, and D. Korčok, "Industry 4.0: The Future Concepts and New Visions of Factory of the Future Development," in International Scientific Conference on ICT and E-Business Related Research, 2016, no. January 2016, pp. 293-298.

[2] Y. Yudhanto, "Apa itu iOt (Internet of Things)?," IlmuKomputer.Com, pp. 1-7.

[3] T. Davies, "Internet of things (IoT)," J. Inst. Telecommun. Prof., vol. 9, no. 4, p. 38, 2015.

[4] A. Firmansyah, "Analisis Tantangan Penerapan Protokol dan Cloud Production Deployment pada Internet of Things dalam Membangun Smart City di Indonesia sebagai Sustainable Development Goals setelah Masa Pandemi COVID-19," no. July, 2020.

[5] I. G. P. S. Gede Saindra Santyadiputra, I Made Putrama, "Pelatihan Internet Of Things( IOT ) Untuk Pelajar Tingkat SMK di Kecamatan Buleleng," in Seminar Nasional Vokasi dan Teknologi, 2017, pp. 105-111.

[6] H. Yuliansyah, "Uji Kinerja Pengiriman Data Secara Wireless Menggunakan Modul ESP8266 Berbasis Rest Architecture," J. Rekayasa dan Teknol. Elektro, vol. 10, no. 2 (Mei 2016), pp. 68-77, 2016.

[7] A. Al Dahoud and M. Fezari, "NodeMCU V3 For Fast IoT Application Development," Notes, no. October, 2018.

[8] N. Hidayati, L. Dewi, M. F. Rohmah, and S. Zahara, "Prototype Smart Home Dengan Modul NodeMCU ESP8266 Berbasis Internet of Things (IoT)," Tek. Inform. Univ. Islam Majapahit, pp. 1-9, 2018. 